\title{
Tecrübeli Satranç Oyuncuları ve Satranca Yeni Başlayan Bireylerin Kognitif Fonksiyonları ve Duygusal Durumlarının İncelenmesi
}

\author{
Necip Kutlu*, Elif Sümeyye Erdemir \\ ${ }^{1}$ Manisa Celal Bayar Üniversitesi, Tıp Fakültesi Tıbbi Fizyoloji Anabilim Dalı Manisa, Türkiye \\ email:kutlunecip@hotmail.com, eserdemir007@gmail.com \\ Orcid:0000-0003-4873-4989 \\ Orcid:0000-0001-7762-9702 \\ *Sorumlu Yazar / Corresponding Author: Sorumlu Yazar: Necip Kutlu \\ Gönderim Tarihi / Received: 09.09.2019 \\ Kabul Tarihi / Accepted:14.10.2019 \\ DOI: $10.34087 /$ cbusbed.617374
}

\begin{abstract}
Amaç: Çalışmada, farklı seviyelerdeki satranç oyuncularının stres altında tepki hızı ve kalitesi (DT), sürekli dikkat/problem çözme yeteneği (COG), muhakeme yeteneği (SPM) ve görsel algılama (TAVTMB) performanslarının ve duygusal durumlarının karşılaştırılması amaçlandı.

Yöntem:Viyana test sistemi beynin zihinsel ve kognitif fonksiyonlarını değerlendirir. Test bataryasında bulunan determinasyon testi (DT) ile bireylerin yoğun uyaran akışı ve stres altında tepki verme hızı ve kalitesi, Cognitrone testi (COG) ile sürekli dikkat-problem çözme yeteneği ve kavramayı, Standart Progressive Matrisler (SPM) analitik irdelemeyi, düzenli düşünmeyi ve soyutlama ile zihinsel faaliyet hızını, Takiskopik Trafik Algılama testi (TAVTMB) ise görsel duyusal bellek performansını değerlendirir. Anksiyete ve depresyonun kognitif fonksiyonu olumsuz etkiler. Gönüllülerin (7-16 yaş) psikolojik durumları nöropsikolojik anketlerden; çocuklarda anksiyete bozukluklarını tarama ölçeği (ÇABTÖ) ve çocuklar için depresyon ölçeği (CDI) ile belilrlendi. Serebral laterizasyonunun da beynin kognitif fonksiyonlarında çeşitli yetenek farklılıklarını sağladığı bilindiğinden sağlaklık ve solaklığı ölçmede kullanılan Edinburg El Tercihi anketi ile tespit edildi.

Bulgular: Orta düzey satranç oyuncularının DT ortalaması ve DT süresi yeni başlayan oyunculara göre anlamlı olarak yüksekti $(\mathrm{p}<0,05)$.Profesyonel satranç oyuncularının ÇABTÖ ve CDI değerleri anlamlı olarak düşüktü( $(\mathrm{p}=0,01)$. Orta düzey satranç oyuncuları ise yeni başlayan oyunculara göre bu değerler düşüktü. Depresyon puanı ortalaması; değerlendirilen gruplar arasında ve yeni başlayan satranç oyuncuları arasında anlamlı( $\mathrm{p}=0,01)$ ilişki tespit edilmiştir
\end{abstract}

Sonuç: $\mathrm{Bu}$ çalışma; satranç oynamanın bireylerde beynin kognitif fonksiyon becerilerinde ve duygusal durumlarında olumlu katkı sağlayabileceğini göstermiştir.

Anahtar Kelimeler:Psikoteknik, Viyena Test Sistemi, Kognitif Fonksiyon, El Tercihi, Eğitimde Satranç, Anksiyete, Depresyon.

\begin{abstract}
Objective:Theaim of this study was to compare the response and quality of stress (DT), continuous attention / problem solving ability (COG), reasoning ability (SPM) and visual perception (TAVTMB) performances and emotional states of chess players at different levels.

Methods: TheVienna test systemassesses the mental and cognitive functions of the brain. With the determination test (DT) in the test battery, individuals' intense stimulus flow and response rate and quality understress, continuousattention-problem solving ability and comprehension with Cognitrone test (COG), Standard Progressive Matrices (SPM) analytical examination, regular thinking and abstraction and the Tachiscopic Traffic Detection test (TAVTMB) evaluates visual sensory memory performance. Anxiety and depression affect cognitive function negatively. Psychological status of the volunteers (7-16 years) is from neuropsychological question naires; Anxiety Disorders Screening Scale (ADSS) and Children Depression Invantary (CDI) were used in the study. Since cerebral laterization is known to provide various skill differences in cognitive functions of the brain, it was determined by the Edinburgh Hand Preference Question naire which was used to measure health and left-handedness.

Results: The mean DT and DT duration of the intermediate chess players were significantly higher than those of the newly started players $(\mathrm{p}<0.05)$. The ADSS and CDI values of Professional chess players were significantly lower
\end{abstract}


$(\mathrm{p}=0.01)$. The intermediate chess players were lower than the new players. Mean depression score; there was a significant relationship between the group sevaluated and the newly started chess players $(\mathrm{p}=0.01)$.

Conclusion: This study; showed that playing chess able to contribute positively to cognitive function skills and emotional states of the brain in individuals.

Key Words:Psychotechnics, Vienna Test System, Cognitive Function, Hand Preference, Chess in Education, Anxiety, Depression.

\section{Giriş}

Avusturyalı Dr. SchuhfriedGes.'in geliştirdiği psikoteknik ölçme ve değerlendirme sistemi bireyi yetenek ve becerileri, zihinsel özelliklerinin süreçlerini, psikomotor performanslarını belirli koșullar altında gözlemlemeye yarayan test sistemidir. Psikoteknik test sistemi kişinin soyut olarak meydana getirdiği davranış, güdü, tutum, savunma, zihinsel faaliyetleri somut ve nesnel bir veri olarak elde etmeyi sağlamaktadır [1] Psikoteknik testlerin kişinin fizyolojik olarak bedensel ve zihinsel performansi ile psikolojik durumunun ölçülmesi sağlanmaktadır. $\mathrm{Bu}$ testleri genel bir sınıflandırma yapmak gerekirse, test gruplarından ilki fizyolojik testler grubu; kas gücü, refleksler, renk körlügü, gözde derinlik yeteneği, dar görüş açısı, görüş keskinliği ölçülmesini hedeflemekte ve somut veriler elde edilebilmesini kolaylaştırmaktadır. İkincisi psikomotor testler grubu; el-göz koordinasyonu, sese1şığa reaksiyon, yaygın ve toplu dikkat, karar verme yeteneği ve süresi, yorgunluk, monotoni, sağlaklıksolaklık, dokunma ve denge durumu, fiziksel ve mental sakatlık, çekme ve itme gücü, hareketi kontrol edebilme yetenekleri gözlemlenebilmekte ve ölçülebilmektedir. Üçüncü olarak psikolojik testler ise zekâ, kişilik, hafıza, alg1, dikkat, öğrenme, zihinsel yetenek, emosyonel durum, fobiler, ilgi ve ustalık testleri gibi birçok farklı alanlarda da kullanılabilecek testleri içeren kapsamlı çalışmalara da fayda sağlayabilecek testler yapilabilmektedir [2]. Satranç oyunu bireylere farklı alanlarda birçok özellikler sağlayıp gelişimine katkıda bulunabilmektedir. Başarıya odaklanma, disiplinli olma, zamanı doğru yönetme ve planlama,konsantrasyon, mantıksal düşünme ve analiz edebilme, birçok açıdan hesaplama yapabilme,göz-beyin koordinasyonunu sağlama, kişinin davranış ve tutumlarından sorumluluk alabilme ve farkındalığında olması gibi benzeri özelliklerini geliştirmesi bakımından satranç ile bağlantılı olarak düşünülebilir. Birçok anne ve babanın çocuklarının eğitiminde zorlandığı konulardan biri de dikkatlerini bir konuya odaklayamaması sorunudur. Halbuki konsantrasyonu sağlayan en önemli etken motivasyon faktörüdür. Her yetişkin birey için de geçerli olduğu gibi çocuklar ancak istediği ve sevdiği konularda zorlamadan yoğunlaşabilmektedir. Böylece satranç sayesinde birey/çocuk konsantre olabilmeyi öğrenebilmekte ve dikkat dağınıklığı probleminin azaldığı görülmektedir. Çocuk günlük hayatta öğrenmesi gereken doğru-yanlış, iyi-kötü hamle ya da davranışlar ile olayları neden-sonuç ilişkisine göre kavramayı henüz satranç oynarken anlayabilmektedir [3].
Dauvergne'in $2000 \quad$ yılındayazdığımakalede; satrancınbireylerin IQ yükselttiği, dil, bellek, okuma ve matematiksel yeteneklerini geliştirdiğini, oblem çözme becerilerini güçlendirdiğini, bağımsız olarak zor ve soyut karar vermeyi öğrettiğini, mantıksal ve verimli düşünmeyi ve çok sayıda seçenekten en iyive ideal olanı seçmeyi öğrettiğini, kısa sure içinde kesin ve hızlı kararlar almayı sağladığını saptamıştır [4].2006 yılında Unterrainer ve arkadaşlarının yaptığı bir çalışmada satranç oyuncularile satranç oynamayanlarda Raven Progressive Matrix testi kullanılarak zekâları değerlendirilmiştir. Bununla birlikte sözel ve görseluzamsal çalışma belleği de değerlendirilmiş ve sonuç olarak satranç oynayanlarla, satranç oynamayanlar arasında herhangi bir fark olmadığı görülmüştür $\square 5 \square$. Burgoyne ve arkadaşlarının yaptığı araştırmada örneklemdeki bireylerin satranç becerileri; uluslararası kuvvet derecelerine (ELO) göre ve kognitif beceri düzeyleri ise RavenProgresif Matris kullanılarak elde edilmiştir.Satranç becerisi, akıcı akıl yürütme, anlama bilgisi, kısa süreli bellek ve işlem hızı; becerileri ile korelasyon uygulanmıştır. Ayrıca, akıcı akıl yürütme ve satranç becerisi arasındaki korelasyon yaşla modellenmiştir. İlginç olarak, satranç becerisi, sözel yetenek veya görsel uzamsal yeteneğe göre sayısal yeteneği ile daha güçlü bir korelasyon göstermiştir. Elde edilen sonuçlar ışı̆̆ında, bilişsel yeteneğin satranç becerisinde, özellikle genç satranç oyuncularında ve/veya daha düşük düzey becerilerin bireysel farklılıklara anlamlı bir katkıda bulunduğunu göstermektedir [6].2012 yılında yapılmış bir başka çalışmada ise 30 sağlak usta satranç oyuncuları ile satranç oyuncusu olmayan 30 sağlak bireyin frontal lob fonksiyonları karşılaştırılmıştır. Her iki grubun frontal lob fonksiyonlarının değerlendirilmesinde Wisconsin Kart Tarama Testi (WCST) ve Stroop Rengi ve Kelime Girișim Testi kullanılmıștır. WCST frontal lob hasarına, özellikle de dorsolateral prefrontal korteks disfonksiyonuna duyarlı olduğu düşünülen nöropsikolojik bir testtir.Usta satranç oyuncuları ile satranç oynamayan bireyler arasında anlamlı bir fark bulunamamıştır [7].Waters ve arkadaşlarının 2002 de görsel hafıza testiyle gerçekleştirildiği bir araştırmada, yetişkin satranç oyuncusu grubunda satranç becerisi ve görsel bellek yeteneği arasında bir korelasyon olduğuna dair bir kanıt bulunamamıştır [8].

Çalışmamızda; lisanslı ulusal kuvvet derecesi (UKD) olan profesyoneller, orta düzeyde deneyimli ve deneyimsiz satranç oyuncu grupları arasında el tercihi ve serebral lateralizasyon öngörüsüyle yoğun uyaran akışı ve stres altında tepki hızı ve kalitesi, sürekli dikkat/problem çözme yeteneği, algılama ve muhakeme 
yeteneği, görsel algılama performansları ve duygusal durumlarının karşılaştırılması amaçlandı.

\section{Gereç ve Yöntem}

Çalışma, Manisa'daki satranç kulüplerinde faaliyet gösteren ve Manisa'da yaşayan 7-16 yaş grubundaki deneyimli ve yeni başlayan satranç oyuncularından ilgili kurumun izin verdiği ve ebeveynlerinin de onayladığ kişilerin katılımı ile çalışma grubu oluşturuldu. Çalışma tecrübeli satranç oyuncuları $(n=10)$ orta düzey satranç oyuncuları $(n=43)$ ve satranca yeni başlayan bireyler $(n=52)$ olmak üzere toplam $(n=105)$ gönüllü bireylerde yapıldı. Bireylerin kilo, boy profili tespit edildi.

Psikoteknik Viyana Test Sistem'inde bulunan, satranç oyuncularının kognitif yeteneklerini ortaya çıkarmak amaciyla belirlenen testlerden sürekli dikkat ve problem çözme yeteneği (COG), muhakeme yeteneği (SPM), tepki hız1-kalitesi (DT) testleri ve Takiskopik Trafik Algılama Testi (TAVTMB) uygulandı. Duygusal durumları ise psikiyatristimiz danışmanlığında Çocuklarda Depresyon Ölçeği (CDI-ÇATÖ), Çocuklarda Anksiyete Bozukluğu Tarama Ölçeği (ÇABTÖ) ile yüzyüze soru-cevap şeklinde uygulanıp, değerlendirildi [9].El tercihi Edinburg anketi ile saptand1 [10].

Tablo 1. EI Tercihi Derecesi, Kognitif Beceri Ortalama ve Standart Sapma Dağılımı

\begin{tabular}{|c|c|c|c|c|c|c|c|c|c|c|c|}
\hline & LK & $\begin{array}{l}\text { COG } \\
\text { Evet }\end{array}$ & $\begin{array}{l}\text { COG } \\
\text { Hayır }\end{array}$ & $\begin{array}{l}\text { COG } \\
\text { Hayır } \\
\text { Süre }\end{array}$ & $\begin{array}{l}\text { COG } \\
\text { Evet } \\
\text { Süre }\end{array}$ & \begin{tabular}{|l} 
DT \\
Doğru \\
Sayısı
\end{tabular} & DT Süre & $\begin{array}{l}\text { SPM } \\
\text { Doğru } \\
\text { Sayısı }\end{array}$ & Tavtmb & Depresyon & Anksiyete \\
\hline $\begin{array}{l}\text { Toplam } \\
\text { Dağılım } \\
(\mathrm{n}=105)\end{array}$ & $\begin{array}{c}62.24 \\
\pm 38.18\end{array}$ & $\begin{array}{l}71.57 \\
\pm 6.22\end{array}$ & $\begin{array}{l}106.54 \\
\pm 13.62\end{array}$ & $\begin{array}{c}4 \\
\pm 1.67\end{array}$ & $\begin{array}{c}3.57 \\
\pm 1.58\end{array}$ & $\begin{array}{c}171.99 \pm \\
30.53\end{array}$ & $\begin{array}{c}1.05 \\
\pm 0.16\end{array}$ & $\begin{array}{c}18.89 \pm 6 \\
.22\end{array}$ & $\begin{array}{l}43.23 \\
\pm 6.23\end{array}$ & $\begin{array}{c}5.99 \\
\pm 4.90\end{array}$ & $\begin{array}{c}23.09 \\
\pm 10.83\end{array}$ \\
\hline $\begin{array}{l}\text { Erkek } \\
(\mathrm{n}=70)\end{array}$ & $\begin{array}{c}59.14 \\
\pm 39.82\end{array}$ & $\begin{array}{l}72.09 \\
\pm 5.52\end{array}$ & $\begin{array}{l}105.59 \\
\pm 15.13\end{array}$ & $\begin{array}{c}3.58 \\
\pm 1.00\end{array}$ & $\begin{array}{c}3.27 \\
\pm 1.02\end{array}$ & $\begin{array}{c}177.97 \pm \\
29.53\end{array}$ & $\begin{array}{c}1.02 \\
\pm 0.14\end{array}$ & $\begin{array}{c}19.5 \pm 6 \\
25\end{array}$ & $\begin{array}{l}44.33 \\
\pm 6.14\end{array}$ & $\begin{array}{c}6.54 \\
\pm 5.31\end{array}$ & $\begin{array}{c}23.53 \\
\pm 10.72\end{array}$ \\
\hline $\operatorname{K} 1 z(n=35)$ & $\begin{array}{c}68.24 \\
\pm 34.88\end{array}$ & $\begin{array}{l}70.56 \\
\pm 7.53\end{array}$ & $\begin{array}{c}108.53 \\
\pm 9.66\end{array}$ & $\begin{array}{c}4.86 \\
\pm 2.36\end{array}$ & $\begin{array}{c}4.21 \\
\pm 2.25\end{array}$ & $\begin{array}{c}160.06 \pm \\
29.78\end{array}$ & $\begin{array}{c}1.13 \\
\pm 0.18\end{array}$ & $\begin{array}{c}17.74 \pm 6 \\
.13\end{array}$ & $\begin{array}{l}40.76 \\
\pm 5.78\end{array}$ & $\begin{array}{c}4.91 \\
\pm 3.82\end{array}$ & $\begin{array}{c}22.65 \\
\pm 10.99\end{array}$ \\
\hline $\begin{array}{l}\text { Sağlak } \\
(n=95)\end{array}$ & $\begin{array}{c}73.89 \\
\pm 11.70\end{array}$ & $\begin{array}{c}71.4 \\
\pm 6.34\end{array}$ & $\begin{array}{l}106.54 \\
\pm 13.57\end{array}$ & $\begin{array}{c}3.97 \\
\pm 1.70\end{array}$ & $\begin{array}{c}3.52 \\
\pm 1.59\end{array}$ & $\begin{array}{c}172.15 \pm \\
30.44\end{array}$ & $\begin{array}{c}1.05 \\
\pm 0.16\end{array}$ & $\begin{array}{c}19.18 \pm 6 \\
.10\end{array}$ & $\begin{array}{l}43.22 \\
\pm 6.12\end{array}$ & $\begin{array}{c}6.16 \\
\pm 4.97\end{array}$ & $\begin{array}{c}23.96 \\
\pm 10.88\end{array}$ \\
\hline $\begin{array}{l}\text { Solak } \\
(n=10)\end{array}$ & $\begin{array}{c}-48.5 \\
\pm 18.86\end{array}$ & $\begin{array}{c}73.2 \\
\pm 5.01\end{array}$ & $\begin{array}{c}102.6 \\
\pm 13.88\end{array}$ & $\begin{array}{c}3.82 \\
\pm 1.76\end{array}$ & $\begin{array}{c}3.53 \\
\pm 2.14\end{array}$ & $\begin{array}{c}161.2 \\
\pm 20.09\end{array}$ & $\begin{array}{c}1 \\
\pm 0.10\end{array}$ & $\begin{array}{c}18.4 \pm 6 \\
92\end{array}$ & $\begin{array}{c}43 \\
\pm 4.47\end{array}$ & $\begin{array}{c}5.5 \\
\pm 3.69\end{array}$ & $\begin{array}{c}29.5 \\
\pm 9.64\end{array}$ \\
\hline $\begin{array}{l}\text { Sağlak } \\
\text { Erkek }(n=6 \\
\text { 2) }\end{array}$ & $\begin{array}{c}72.58 \\
\pm 11.55\end{array}$ & $\begin{array}{l}71.84 \\
\pm 5.56\end{array}$ & $\begin{array}{c}105.5 \\
\pm 15.16\end{array}$ & $\begin{array}{c}3.55 \\
\pm 0.96\end{array}$ & $\begin{array}{c}3.21 \\
\pm 0.96\end{array}$ & $\begin{array}{c}177.03 \pm \\
29.72\end{array}$ & $\begin{array}{c}1.02 \\
\pm 0.15\end{array}$ & $\mid \begin{array}{c}19.76 \pm 6 \\
.20\end{array}$ & $\begin{array}{l}44.21 \\
\pm 6.28\end{array}$ & $\begin{array}{c}6.74 \\
\pm 5.44\end{array}$ & $\begin{array}{c}24.26 \\
\pm 10.92\end{array}$ \\
\hline $\begin{array}{l}\text { Sağlak } \\
\text { Kız(n=33) }\end{array}$ & $\begin{array}{c}76.34 \\
\pm 11.74\end{array}$ & $\begin{array}{l}70.58 \\
\pm 7.61\end{array}$ & $\begin{array}{c}108.48 \\
\pm 9.85\end{array}$ & $\begin{array}{c}4.76 \\
\pm 2.40\end{array}$ & $\begin{array}{c}4.76 \\
\pm 2.40\end{array}$ & $\begin{array}{c}162.97 \pm \\
30.09\end{array}$ & $\begin{array}{c}1.11 \\
\pm 0.18\end{array}$ & $\begin{array}{c}18.09 \pm 5 \\
.85\end{array}$ & $\begin{array}{l}41.36 \\
\pm 5.42\end{array}$ & $\begin{array}{c}5.06 \\
\pm 3.78\end{array}$ & $\begin{array}{c}23.39 \\
\pm 10.96\end{array}$ \\
\hline
\end{tabular}

Psikolojik ve kognitif yetenekleri belirlemek için, standardize edilmiş ve uluslararası normlara uygun objektif veri elde etmek amaciyla Tıp Fakültesi Dekanlık Binamızda bulunan "Psikometrik ve Psikomotor Ölçme ve Değerlendirme testler uygulanarak ölçüm yapıldı. Tüm testler IBM SPSS Statistics 20) ile değerlendirildi. Analizlerde Kruskal-Wallis testi yöntemi uygulandı. $P$ değeri $p<0,05$ ise anlamlı kabul edildi.

\section{Bulgular}

Erkek ve kız satranç oyuncularının Tablo 1 de görüldüğü gibi el tercihi derecesi (LK), dikkat (COG), muhakeme yeteneği (SPM), tepki hızı-kalitesi (DT) ve görsel hafiza (TAVTMB) ve CDI-ÇATÖ), çocuklarda anksiyete bozukluğu tarama ölçeği (ÇABTÖ) ortalama ve standart sapması gösterilmiştir. Sağlak ve solak bireylerde bu değerler arasındaki fark istatistiksel olarak anlamlı değildi. Bireylerin $(n=95)$ sağlak bireylerin çoğunlukta olması örneklemin homojenize olması açısından önemlidir. Laboratuvarımızda olan Standart İzole Test Odasında 
Çalışmamızda sağlakların tepki hızı ve kalitesi ortalaması (DT), solakların tepki hızı ve kalitesi ortalamasına göre yüksek olduğu görülmesine rağmen istatistiksel olarak anlamlı farklılık saptanamadı. $(\mathrm{p}>0,05)$.

\section{Şekil 1. Toplam El Tercihi Dağılımı}

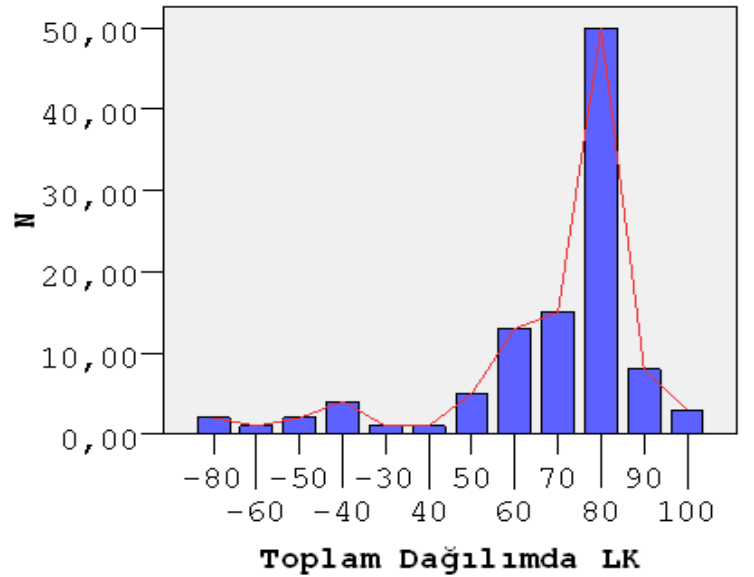

Şekill. de total örneklemde el tercihi dağılım derecesi görülmektedir. El tercihi dağılımı literatüre göre uyumlu olarak asimetrik dağılım saptanmıştır.

Tablo 2 de yeni başlayan, orta düzey ve profesyonel satranç oyuncularının kognitif beceri ortalamaları ve standart sapmaları gösterilmiştir.

Tablo 2. Satranç Gruplarının, Kognitif Beceri Ortalama Tabloları

\begin{tabular}{|c|c|c|c|c|c|c|c|c|c|c|c|}
\hline & LK & $\begin{array}{l}\text { COG } \\
\text { Evet }\end{array}$ & $\begin{array}{l}\text { COG } \\
\text { Hayır }\end{array}$ & \begin{tabular}{|l} 
COG \\
Hayır \\
Süre \\
\end{tabular} & \begin{tabular}{|l} 
COG \\
Evet \\
Süre \\
\end{tabular} & \begin{tabular}{|l|} 
DT \\
Doğru \\
Sayısı \\
\end{tabular} & $\begin{array}{l}\text { DT } \\
\text { Süre }\end{array}$ & $\begin{array}{l}\text { SPM } \\
\text { Doğru } \\
\text { Sayısı } \\
\end{array}$ & Tavtmb & Depresyon & Anksiyete \\
\hline $\begin{array}{l}\text { Prof. } \\
\text { Oyuncular }\end{array}$ & $\begin{array}{c}46.45 \\
\pm 48\end{array}$ & $\begin{array}{l}59.05 \\
\pm 4.79\end{array}$ & $\begin{array}{c}46.7 \\
\pm 8.62\end{array}$ & $\begin{array}{c}3.92 \\
\pm 1.04\end{array}$ & $\begin{array}{c}3.53 \\
\pm 0.82\end{array}$ & \begin{tabular}{|c|}
165 \\
\pm 19.9 \\
5 \\
\end{tabular} & $\begin{array}{c}1.09 \\
\pm 0.12\end{array}$ & $\begin{array}{c}18.90 \\
\pm 8.1\end{array}$ & $\begin{array}{c}42.70 \\
\pm 6.7\end{array}$ & $\begin{array}{l}29.65 \\
\pm 2.55\end{array}$ & $\begin{array}{c}13.5 \\
\pm 6.55\end{array}$ \\
\hline $\begin{array}{ll}\text { Orta } & \text { düzey } \\
n=43 & \\
\end{array}$ & $\begin{array}{c}46.84 \\
\pm 37\end{array}$ & $\begin{array}{l}53.08 \\
\pm 5.90\end{array}$ & $\begin{array}{c}57.77 \\
\pm 12.33\end{array}$ & $\begin{array}{c}3.91 \\
\pm 1.57\end{array}$ & $\begin{array}{c}3.53 \\
\pm 1.56\end{array}$ & $\begin{array}{l}180 \\
\pm 35\end{array}$ & $\begin{array}{c}1.02 \\
\pm 0.20\end{array}$ & $\begin{array}{c}19.83 \\
\pm 6.7\end{array}$ & $\begin{array}{c}43.16 \\
\pm 6.6\end{array}$ & $\begin{array}{l}50.02 \\
\pm 5.26\end{array}$ & $\begin{array}{c}22.44 \\
\pm 10.75\end{array}$ \\
\hline $\begin{array}{l}\text { Yeni } \\
\text { başlayan } \\
n=52\end{array}$ & $\begin{array}{c}59.36 \\
\pm 36\end{array}$ & $\begin{array}{l}51.77 \\
\pm 6.75\end{array}$ & $\begin{array}{c}50.27 \\
\pm 15.36\end{array}$ & $\begin{array}{c}4.08 \\
\pm 1.85\end{array}$ & $\begin{array}{c}3.61 \\
\pm 1.71\end{array}$ & $\begin{array}{l}166 \\
\pm 26\end{array}$ & $\begin{array}{c}1.06 \\
\pm 0.12\end{array}$ & $\begin{array}{l}18.09 \\
\pm 5.29\end{array}$ & $\begin{array}{c}43.38 \\
\pm 5.8\end{array}$ & $\begin{array}{l}59.95 \\
\pm 4.73\end{array}$ & $\begin{array}{c}25.46 \\
\pm 10.58\end{array}$ \\
\hline
\end{tabular}

Şekil 2. Erkeklerde ve Kızlarda EI Tercihi Dağılımı

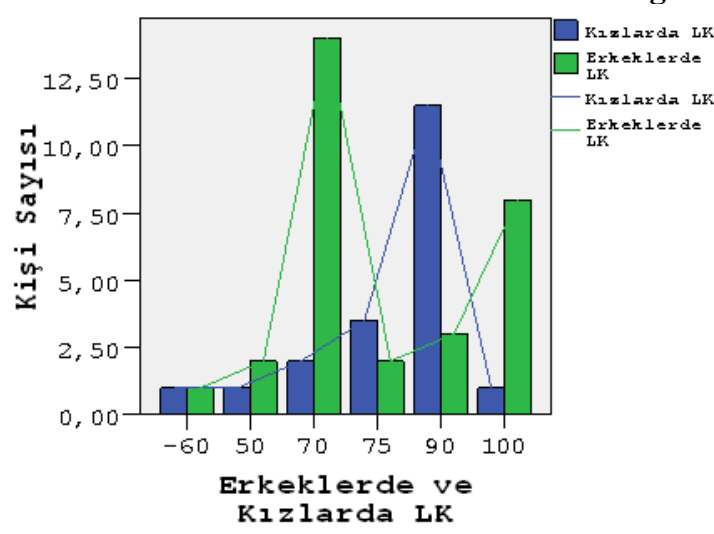

Şekil 2'de kız ve erkeklerde el tercihi derecesi dağılımı verilmiştir. El tercihi dağılımı kızlarda sağlaklık katsayıs1 erkeklere göre daha yüksek, erkeklerde ise tam tersi olarak solaklık katsayısı Kızlara göre daha yüksek olduğu saptandı. Yani kadınlar daha çok sağlak erkekler daha çok solak olduğu literatüre uygun olarak gözlemlendi. Gruplar arasında el tercihi öngörüsüyle kognitif fonksiyonlar ve duygusal durum arasında istatistiksel olarak bir ilişki bulunmadı.
Şekil 3.Satranç Grupları İle DT Ortalaması

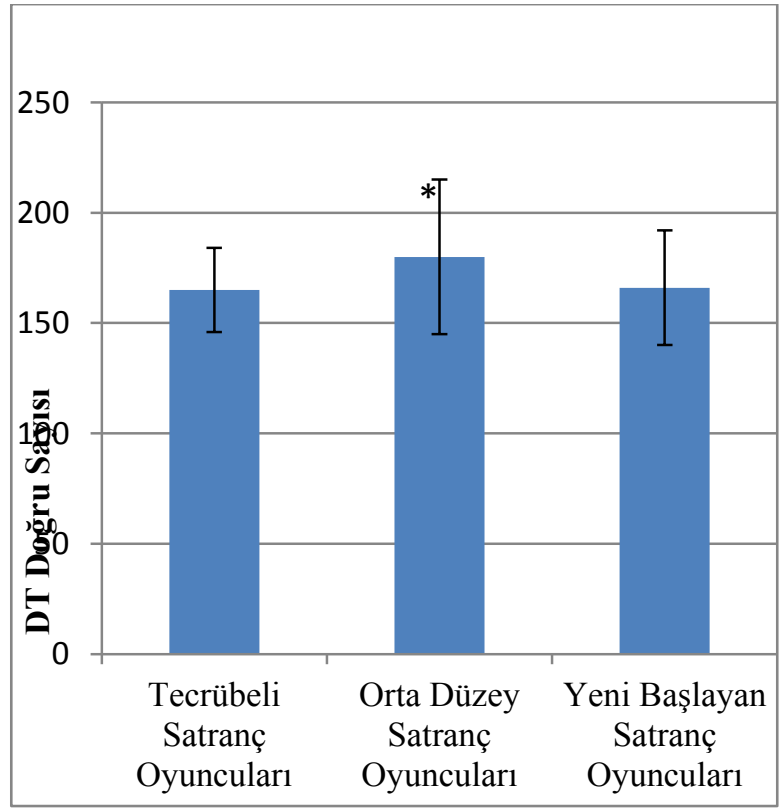


Şekil 3.'e göre satranç oyuncuları arasında orta düzey oyuncuların DT ortalaması yeni başlayan oyuncuların DT ortalamasına göre yüksek düzeyde ve anlamlı $(\mathrm{p}<0,05) \quad$ olduğu görülmüştür. Ancak profesyonel oyuncular ile yeni başlayanlar arasında istatistiksel olarak anlamlı bir farklılık yoktu.

\section{Şekil 4. Satranç Grupları ile DT Süre Ortalaması}

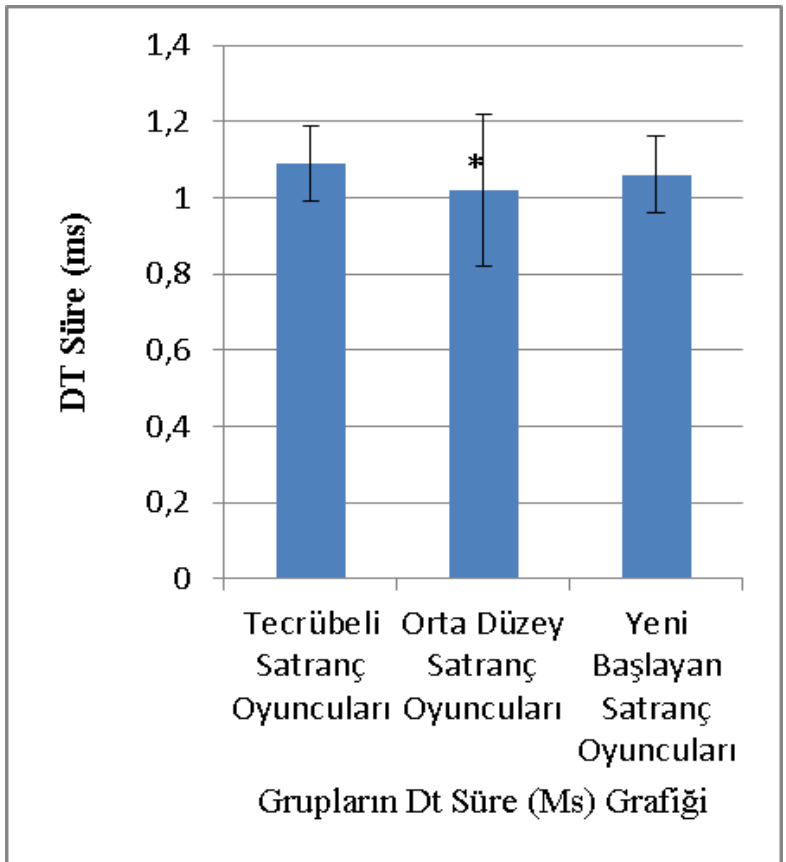

Satranç oyuncuları Şekil 4 görüldüğü gibi profesyonel oyuncuların DT süresi ortalaması orta düzey oyuncuların DT süre ortalamasına göre yüksek düzeyde ve anlamlı $(\mathrm{p}<0,05)$ olduğu saptandı.

Şekil 5. Satranç Grupları ile Anksiyete ve Depresyon Puanı Ortalaması

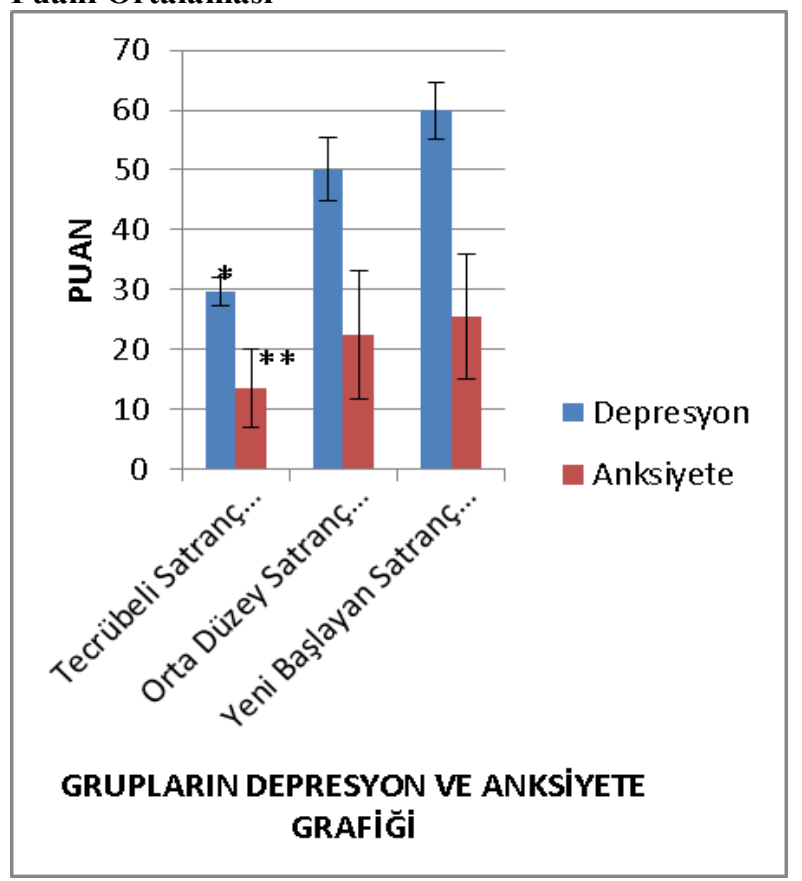

$*=p<0,05$

$* *=p=0,004$
Satranç oyuncularından oluşan gruplar (yeni başlayan, orta düzey, profesyonel) Şekil 5'te depresyon ve anksiyete ortalama puanı dağılımı görülmektedir.

Depresyon puanı ortalaması; değerlendirilen gruplar arasında profesyonel satranç oyuncuları ile orta düzey ve yeni başlayan satranç oyuncuları arasında anlamlı $(p=0,01)$ ilişki tespit edilmiştir. Buna göre profesyonel satranç oyuncularının depresyon puanı ortalaması, orta düzey ve yeni başlayan satranç oyuncularına göre daha düşük çıkmıştır.

Anksiyete puanı ortalaması profesyonel satranç oyuncularının; orta düzey ve yeni başlayan satranç oyuncularına göre daha düşük ve aralarında oldukça anlamlı $(\mathrm{p}=0,004)$ ilişski olduğu bulundu.

Cinsiyet faktörü göz önünde bulundurulduğunda her satranç grubuna yeterli sayıda gönüllü temin edilememiş olmasından dolayı istatistiksel olarak değerlendirilmesi yapılamamıştır.

Kognitif becerileri ölçen diğer test sonuçları grupların homojen dağılmaması sebebiyle gruplar arasında COG, SPM, TAVTMB test sonuçlarında anlamlı bir farklılık bulunmamıştır. $(\mathrm{p}>0,05)$

\section{Tartisma}

Üniversite öğrencilerinde yapılan araştırmada; solakların, sağlaklara oranla daha yavaş olup el beceri sürelerinin uzadığı tespit edilmiştir. Bizim tepki hızı ve kalitesi sonuçlarıyla uyumludur [11] Araştırmamızda sağlak erkeklerin tepki hızı ve kalitesi ortalaması ile sağlak kızların ortalamasına göre daha yüksek olduğu saptanmıştır. Ancak istatistiksel olarak anlamlı farklılık saptanamadi( $p>0,05)$. Kelecek ve arkadaşlarının araştırmasında; erkeklerin kızlara göre odaklanma ve motivasyon başarılarının daha yüksek olduğu bulunmuştur [12].

Satranç oyuncularının zaman baskısı altında karar alma süreçlerinde elektroensefalografik tepkisinin ölçüldüğü bir çalışmada satranç oyuncularının hızlı yanıtlarının ön parietal alanlardaki yüksek teta aktivasyonu ile sağlandığını görmüşlerdir [13].Satranç oyununun, stres altında iken oyuncu üzerinde nasıl bir etki yarattığını gözlemleyen bu araştırma çalışmamızla uyum sağlayacak niteliktedir. Bir araştırmada satranç oyunu esnasında, sınırlandırılmış süre ile strese girmeleri sağlanmış profesyonel oyuncuların, profesyonel olmayan oyunculara göre daha uzun süre düşünerek süreyi uzattıkları fakat daha etkin performans sergiledikleri görülmüştür.

Yapılmış olan bir araştırmada zaman baskısının satranç becerisi üzerine etkisi incelendiğinde iyi düzeyde olan oyuncuların, satranç becerisi daha az olan oyunculara göre ortam şartlarını ve başarıya ulaşmada kullanması gereken araçları yöntem ve süre olarak daha etkin kullanabildikleri gözlenmiştir [14]. Profesyonel oyuncuların stres altında soğukkanlılıklarını korudukları 
ve düşünerek hareket ettikleri sonucunu düşündürmektedir.

Satranç eğitimi alan ve almayan öğrencilerde üzerinde yapılan bir çalışmada; satranç eğitimi alan öğrencilerin öz güven, girişken ve problem çözmede daha başarılı olduğu gösterilmiştir[15]. Sonuçlar ele alındığında satrançta deneyimin artmasının, depresif duygu durumunu azalttığı söylenebilir.

Sportif aktivitelere katılan aralarında satranç sporcularının yer aldığı bireyler üzerinde yapılmış çalışmada anksiyete düzeyleri incelendiğinde diğer oyunculara göre sürekli kaygı düzeylerinin düşük olduğu tespit edilmiştir [16].

Tüm gruplarda; COG evet-hayır yanıtları ve sürelerinde çalışmamızla uyumlu olarak bir araştırmada satranç oyuncusu olan ve olmayan bireylerde odaklanma ve dikkat becerisi verileri arasında anlamlı bir ilişki olmadığı [7], SPM test puanı sonuçlarımız ile yapılan çalışmada zekânın satranç becerisinde önemli bir etken olmadığ araştırmanın satranç oyuncularının görsel-uzamsal yetenekleri ile satranç becerisi arasında anlamlı bir ilişki bulamamışlardır [8]. Araştırmanın sonuçlarının literatüre uygunluk gösterdiği bulunmuştur.

\section{Sonuç}

Satranç oyunu beynin bilişsel işlevleri geliştirebileceği ve duygusal yönden destekleyerek yaşam kalitesinin yükselmesi açısından önemli olabileceğini düşünmekteyiz. Toplumsal açıdan satranç oyununun önemi; ebeveyn ve çocukları bilinçlendirme faaliyetleri gösterilmesinin çocukların stresle baş etmelerinin sağlanmasında, anksiyete-depresyon düzeylerinin azalmasında ve sosyal uyumlarında yararlı olabileceği kanaati oluşmuştur.

\section{Kaynaklar}

1. Birmaher B, Khetarpal S, Brent D, Cully M, Balach L.,Kaufman J, Neer S. $\quad$ M. Thescreenforchildanxietyrelatedemotionaldisorders (SCARED):

Scaleconstructionandpsychometriccharacteristics. Journal of theAmerican Academy of Child \&AdolescentPsychiatry, 1997; 36(4), s:545-553.

2. Oldfield RC. Theassessmentandanalysis of handedness: theedinburghinventory.Neuropsychologia. 1971;9: 97-113.

3. Durak N, Gürcan B, Koru M, olșen C. A, Özer D Üniversite öğrencilerinde içilen kahvenin el beceri hız performansı üzerine etkilerinin incelenmesi. Xv. Öğrenci Sempozyumu CCalışma Grubu Sunumları, Başkent Üniversitesi Tıp Fakültesi, 14-16 Mayıs 2013.

4. Kelecek S, Așçı F. H, Altıntaş A. Elit erkek ve kadın voleybolcuların algıladıkları güdüsel iklimin, güdüsel yönelimlerini ve optimal performans duygu durumlarını belirlemedeki rolü. Gazi Beden Eğitimi ve Spor Bilimleri Dergisi Ekim 2010; Xv(4), s: 42-43.

5. Villafaına, Santos, et al. Electroencephalographicresponse of chessplayers in decision-makingprocessesunder time pressure. Physiology\&behavior, 2019, 198: 140-143.

6. Van Harreveld, Frenk; Wagenmarkers, Eric-jan; Van Der Maas, Han LJ. Theeffects of time pressure on chessskill: an investigationintofastandslowprocessesunderlyingexpertperf ormance, Psychologicalresearch, 2007, 71.5: 591-597.

7. Gül Ş, Serin N. B. KKTC'de satranç eğitimi alan ve almayan ilkokul ve orta okul ögrencilerinin problem çözme becerilerine yönelik algıları. International JournalOfNewTrends in Arts, Sports \&ScienceEducationaljtase 2017; 6.3 s:64.

8. Aydın E. Üniversite spor şenlikleri içerisinde yer alan sportif faaliyetlere katılan personelin kaygı düzeylerinin belirlenmesi. TurkishJournal of EducationalStudies 2017; 4(1).

9. Bilalić $\mathrm{M}$, McLeod $\mathrm{P}$, Gobet F. Doeschessneedintelligence?-A studywithyoungchessplayers. Intelligence 2007; 35(5), s:457-470.

10. Erim E, Hazar M, Tekin M. Satranç oynayan ve oynamayan ilköğretimöğrencilerinin problem çözme becerilerinin incelenmesi. Journal Of PhysicalEducationAndSportSciences. 2009; 11.2, s: 2-8.

11. Dauvergne P. Thecaseforchess as a tooltodevelopourchildren'sminds, RetrievedMay. 2000; 18, 2004.

12. Unterrainer JM, Kaller CP, Halsband U, Rahm B. Planning abilitiesandchess: acomparison of chessandnonchessplayers on theTower of Londontask. BrJPsychol. 2006;97(Pt 3):299-311.

13. Burgoyne A. P, Sala G, Gobet F, Macnamara B, Campitelli G, Hambrick D. Z. Therelationshipbetweencognitiveabilityandchessskill: a comprehensivemetaanalysisIntelligence. 2016;59, s:72-83.

14. Nejati M, Nejati V. Frontallobefunction in chessplayers. ActaMedicaIranica.2012; 50.5: 311 .

15. Waters A. J, Gobet F, Leyden G. Visuospatialabilities of chessplayers. BritishJournal of Psychology. 2002;93(4), s:557-565.

16. Aydın E. Üniversite spor şenlikleri içerisinde yer alan sportif faaliyetlere katılan personelin kaygı düzeylerinin belirlenmesi. TurkishJournal of EducationalStudies 2017; 4(1).

17. Bilalić $\mathrm{M}$, McLeod $\mathrm{P}$, Gobet $\mathrm{F}$. Doeschessneedintelligence?-A studywithyoungchessplayers. Intelligence 2007; 35(5), s:457-470.

http://edergi.cbu.edu.tr/ojs/index.php/cbusbed isimli yazarın CBU-SBED başlıklı eseri bu Creative Commons Alınt-Gayriticari4.0 Uluslararası Lisansı ile lisanslanmıştır. 